\title{
Are there gender-related influences on corporate sustainability? A study of women on boards of directors
}

\section{Jeremy Galbreath}

Graduate School of Business, Curtin University, Perth, WA, Australia

\section{ABSTRACT}

This study sought to investigate if there is a link between women on boards of directors and corporate sustainability. Using a sample of publicly listed firms from Australia, the results suggest some level of support that a link does exist. Boards that have a strong complement of gender diversity are expected to offer more effective monitoring of agents, as well as offer more stringent enforcement of ethical conduct, thereby minimizing affects of subversion of shareholder funds that can be detrimental to their returns. Accordingly, findings confirm a positive link between women on boards and economic growth. Because of their relational abilities, women on boards are more likely able to engage with multiple stakeholders and respond to their needs, resulting in an avenue for demonstrating social responsiveness, which is confirmed by the results. However, due to their backgrounds and work experiences, sex-based biases and stereotyping might exist in boardrooms with men directors discounting input from women directors on issues relating to environmental quality. The results of this study find that women directors are not significantly associated with environmental quality. Discussion is given to these findings along with paths for future research.

Keywords: corporate governance, corporate sustainability, board structure, gender diversity, women

Sustainability is perhaps one of the most decision makers need to respond to in the pursuit of competitive success today (Bansal, 2005; Konrad, Steurer, Langer, \& Martinuzzi, 2006; Steurer, Langer, Konrad, \& Martinuzzi, 2005). Leading sustainability scholar Bansal (2001, p. 48) suggests that firms who do not respond to sustainability will 'almost certainly face extinction'. Similarly, others suggest that the ability to integrate sustainability into their corporate mission and into relationships with stakeholders will define which firms will succeed in the twenty-first century and which will fall (e.g., Bacon, 2007; Stranislaw, 2007). In light of these bold assertions, it is clear that understanding how firms respond to sustainability is an important area of enquiry.

To date, research has been particularly focused on understanding why firms commit to sustainability. Results suggest that stakeholder influence is an important factor that determines firms' sustainability practices. Sharma and Henriques (2005) find that stakeholders such as major customers, environmental groups, and employees have a positive influence on levels of sustainability practices. On the other hand, Bansal (2005) finds that international experience, media pressure, mimicry, and organizational size are positively related to corporate sustainability. Sharma and Henriques (2005), however, suggest that further study of internal drivers is 
needed, because studying such drivers could reveal how organizations develop an understanding of sustainability and begin to act on this understanding. Of particular interest is understanding if women on boards of directors are linked with sustainability.

Boards of directors are the ultimate decisionmaking group within corporations (Hendry \& Kiel, 2004). As such, they wield substantial power and responsibility in overseeing firms, having significant influence on strategy that, in turn, affects subsequent performance (Fama \& Jensen, 1983a, 1983b; Hillman, Keim, \& Luce, 2001; Lynall, Golden, \& Hillman, 2003). Therefore, determining the right composition of board members is of critical importance. In general, board composition that includes gender diversity has been one of the most significant governance issues facing modern corporations (Singh, Terjesen, \& Vinnicombe, 2008). One reason for this is that gender diversity has been advocated as a means of improving organizational value and performance by inculcating boards with new insights, new information and new perspectives (Carter, Simkins, \& Simpson, 2003; Miller \& del Carmen Triana, 2009). In the case of meeting the sustainability challenge, new insights and fresh perspectives at the board level are likely to be important.

For example, the nature of sustainability requires understanding, commitment, and action not only towards economic stakeholders (shareholders, investors), but to a broad array of actors including employees, communities, suppliers and governments (Bansal, 2005; Konrad et al., 2006; Sharma \& Henriques, 2005). The ability to address such diverse and potentially conflicting stakeholder pressures and demands is complicated at best (Mitchell, Agle, \& Wood, 1997). However, evidence suggests that women are particularly adept at problem-solving, which affords them strong skills to deal effectively with ambiguity, conflict, and uncertainty (Rosener, 1995). Further, given their orientation towards supporting and maintaining relationships, the work of Biggins (1999) suggests that women better represent the needs of all stakeholders than men, which should aid in decision making and policy development in an area such as sustainability.

Scholars and practitioners alike are showing increased interest in sustainability. However, research examining links between gender diversity on corporate boards and sustainability has yet to be thoroughly qualified and investigated (Ricart, Rodríguez, \& Sánchez, 2005). Thus, the present study makes three contributions to the literature. First, a small but growing stream of research has examined links between women on boards and firm economic performance (e.g., Bonn, 2004; Carter et al., 2003; Catalyst, 2004; Rose, 2007). This type of research is limited given the current climate, where economic results are no longer the sole criterion for how firms are valued in the market; environmental and social outcomes are also important criterion (Hart \& Milstein, 2003; Mercer Investment Consulting, 2006; Victoria López, Garcia, \& Rodriguez, 2007). Unfortunately, no empirical research has simultaneously explored links between women on boards and the three dimensions of sustainability in Australia. This study responds to the research gap. Second, building on gender diversity perspectives, women on boards are argued to enhance effective monitoring of firm agents, demonstrate more effective enforcement of the ethical attitude of a firm than men and improve stakeholder relationships, each in turn which are predicted to impact sustainability. However, women on boards might be limited in their ability to impact on all dimensions of sustainability, for example, due to sexbased biases or stereotyping. By developing and testing the hypotheses with a sample of Australian firms, this article expands our understanding of the potential value - and inhibiters - of women on boards and the sustainability paradigm. Lastly, a call for more women on boards has been a rallying cry for many years in industrialized countries. In the face of the challenges of sustainability, evidence from this research is significant for management researchers and practitioners. This study will allow scholars to offer relevant advice on the likely affects of various board structures on 
sustainability. Practitioners, on the other hand, will have empirical evidence to verify whether or not women on boards might assist them to address sustainability effectively.

\section{CONCEPTUALIZATION OF CORPORATE SUSTAINABILITY}

While there is no universally accepted definition of sustainability (Montiel, 2008), researchers have generally understood sustainability to mean 'meeting the needs of the present without compromising the ability of future generations to meet their own needs' (WCED, 1987, p. 43). Several scholars have followed the definition of the World Commission on Economic Development to conceptualize sustainability, at the firm level, as consisting of three interlocking principles: (1) economic growth; (2) environmental quality; and (3) social responsiveness (Bansal, 2001, 2005; Elkington, 1997; Konrad et al., 2006; Steurer et al., 2005; Wilson \& Lombardi, 2001).

\section{Economic growth}

Private business acts as the vehicle for economic progress and growth (Henderson, 2005). Economic growth is resultant from competitive, market-based activities; namely, from the valuecreation activities of firms (Mizik \& Jacobson, 2003). Firms create value when they provide customers with products and services they wish to buy. According to Porter (1985) and Conner (1991), firms increase value creation through innovation in products and services, by lowering costs of inputs or by realizing efficiencies in scale and scope. When firms create and capture value, consumers benefit through better products and services, shareholders benefit through dividends and increases in the value of equity, employees benefit through salaries and society benefits through higher living standards (Holliday, Schmidheiny, \& Watts, 2002). However, in the process of value creation by firms, natural resource depletion, environmental degradation, and the disruption of community and worker welfare and health can be potential negative externalities imposed on society; thus, in the conceptualization of corporate sustainability, economic growth is tied intrinsically to environmental quality and social responsiveness, as these two aspects are fundamental to any sustainable economic activity (Bansal, 2001, 2005; Schmidheiny, 1992; Steurer et al., 2005).

\section{Environmental quality}

Economic activity invariably impacts the natural environment, including decreases in biodiversity, ozone depletion, greenhouse gas emissions, waste byproducts, and deforestation (Doering et al., 2002). Thus, all firms have an environmental impact, whether in the form of lighting office facilities to the waste and emissions generated from the production process. More specifically, scholars have identified three main footprints with respect to addressing environmental quality. First, firms can control pollution through responsible waste disposal (Hart, 1995; Russo \& Fouts, 1997). Second, Klassen and Whybark (1999) suggest that firms can minimize greenhouse gas emissions through the innovative use of processes and technologies in the production process. Lastly, firms can engage in product stewardship by using fewer materials in producing a product and by disassembling for recycling or reuse at the end of the product lifecycle (Hart, 1995). If the natural environment is compromised currently, future generations will be limited in their ability to access basic resources such as clear air and water (WCED, 1987), highlighting the importance of environmental quality to the triad principles of sustainability.

\section{Social responsiveness}

Firms are increasingly required to respond to social issues (Aguilera, Rupp, Williams, \& Ganapathi, 2007). Social issues are issues that are problematic to society (Mahon \& Waddock, 1992). General examples include AIDS, poverty, and obesity. However, social issues can also be very specific to firms, such as working conditions, product safety, and equal rights (Dobbin \& Sutton, 1998). 
Carroll (1979) further argues that firms have responsibilities to the communities they operate in, including building social capital via volunteering and contributing money to various cultural enterprises, for example. What such viewpoints suggest is that firms have responsibilities to society, not just shareholders. Capturing this perspective, Donaldson and Dunfee (1994) stipulate that firms are obligated to demonstrate responsible behavior to all stakeholders, whether inside or outside corporate walls, making social responsiveness an important dimension of sustainability (cf. Elkington, 1997; Konrad et al., 2006; Steurer et al., 2005). Thus, the assumption in this article is that under the sustainability paradigm, firms have a responsibility to ensure that economic growth is achieved through the demonstration of environmental quality and social responsiveness (Galbreath, 2009a) (Table 1).

\section{THEORETICAL FRAMEWORK AND HYPOTHESES}

In recent years, diversity has become one of the most important variables of study in board of director research (Kang, Cheng, \& Gray, 2007). Diversity includes attributes such as race, nationality, age, and gender. Although there is the potential for tension and conflicts (Jehn, 1995), proponents argue that in group settings, such as boards of directors, diversity results in a greater variety of ideas, perspectives,

TABLE 1: DIMENSIONS OF CORPORATE SUSTAINABILITY

\begin{tabular}{|c|c|c|}
\hline $\begin{array}{l}\text { Dimension of } \\
\text { sustainability }\end{array}$ & $\begin{array}{l}\text { Representative } \\
\text { stakeholders }\end{array}$ & Core aspect \\
\hline Economic growth & Shareholders, investors & $\begin{array}{l}\text { Creating value in a way } \\
\text { that enables a company } \\
\text { to remain economically } \\
\text { viable for an indefinite } \\
\text { time }\end{array}$ \\
\hline
\end{tabular}

Environmental quality

Natural environment/ ecosystems, customers, communities, suppliers

Social responsiveness
Employees, customers, communities
Limiting impact of firm activities on the natural environment while minimizing the use of natural capital

Continually contributing to the social well-being of society and individuals
Key examples

Sufficient cash flow to ensure liquidity; persistent returns to capital providers; R\&D investment; an asset base that the market evaluates as having future value-creation potential
Various emission reduction actions in company facilities and processes; various resource-saving actions in company facilities and processes; energy efficiency in operations; risk assessment of impacts on natural environment; reduced environmental impact of products/services

Job evaluation systems; fair trade; work-life balance; human rights; codes of ethics; employee training; health and safety precautions; product safety; sponsorships and donations 
knowledge, creativity and innovation, and therefore becomes a competitive advantage (Carter et al., 2003); this hypothesis has empirical support (Jehn, Northcraft, \& Neale, 1999). In this section, I draw on diversity perspectives generally, and gender diversity perspectives (de Luis-Carnicer, MartinezSánchez, \& Pérez-Pérez, 2008; Francoeur, Labelle, \& Sinclair-Desgagné, 2008; Miller \& del Carmen Triana, 2009) specifically, to posit how women on boards are likely to be a positive influence, while at the same time, might be restricted in the full extent to which they have a voice to address all dimensions of sustainability equally.

\section{Possibility of positive gender-related influence on corporate sustainability}

In arguing for greater gender diversity on boards, some have suggested that women appointees would raise the confidence of investors, who expect increasing accountability, transparency, and moral duty from firms' directors (Arfken, Bellar, \& Helms, 2004; Brown, Brown, \& Anastasopoulos, 2002; Flynn \& Adams, 2004). For example, compared with 68 percent of allmale boards, 94 percent of boards where women are represented ensure that conflict of interest guidelines are enforced. Further, 86 percent of boards where women are represented ensure that their firms have enforced codes of ethical conduct in place compared with 66 percent of all-male boards (Brown \& Brown, 2001). For many shareholders, there is a perception that boards who have more women appointees do a better job of ensuring that their investments are not in conflict with managerial misappropriation, while at the same time believe that more women representation on boards leads to stronger enforcement of ethical conduct (Brown \& Brown, 2001; Flynn \& Adams, 2004). Governance over misappropriation of shareholder funds and ethical conduct should result in higher economic growth. There are two perspectives for this line of reasoning.

First, according to agency theory (Jensen \& Meckling, 1976), managerial opportunism can subvert shareholder interests; i.e., returns on their investment. Noreen (1988) and Williamson (1985) argue that managers (agents) can, and do, act unreservedly in their own narrowly defined self-interest with, if necessary, guile and deceit. For example, managers may ensure they receive substantial pay increases, extravagant perks, and the like, through the misuse of shareholder funds and free cash flows (Fama, 1980; Fama \& Jensen, 1983a, 1983b; Jensen, 1986; Jensen \& Meckling, 1976). However, following Brown and Brown (2001) and Flynn and Adams (2004), the expectation is that as boards reach a 'critical mass' (Konrad, Kramer, \& Erkut, 2008) of women directors, their influence is likely to be strong in the oversight of investor funds, helping to ensure the minimization of conflicts of interests between shareholders and managers. This should position their firms to maximize economic returns.

Second, transaction cost theory suggests that markets and [firm] hierarchies are alternative forms of coordinating transactions in business exchanges (Williamson, 1975, 1985). If unethical behavior is present, costs can increase because of the expense of writing and monitoring enforceable contracts. In turn, this potentially reduces shareholder returns. Alternatively, where ethical conduct is present, this may reduce transaction costs because fewer protective devices are needed if the firm has trustworthy agents and less time is spent in negotiation if initial claims are truthful (Barney \& Hansen, 1994; Hosmer, 1995; Williamson, 1985). Thus, the costs of ethical conduct are less, which impacts positively on economic growth as profits are diverted from writing and enforcing contracts. Based on the research of Brown and Brown (2001), because women on boards more readily ensure that codes of ethics are in place and enforced than men, the expectation is that they are likely to offer some level of protection against the misuse of shareholder funds, stemming from the promotion of underlying ethical behavior, thereby impacting on the ability of a firm to generate economic growth. Therefore, 
Hypothesis 1: There is a positive relationship between women on boards and the economic growth dimension of sustainability

While economic growth remains a prominent responsibility of corporate oversight and governance, current thinking suggests that boards have to keep their activities and decisions attuned to society's aspirations (e.g., Bhimani \& Soonawalla, 2005; Jamali, Safieddine, \& Rabbath, 2008; Tirole, 2001). Such aspirations come from a variety of stakeholders (Sharma \& Henriques, 2005), not just shareholders. For example, while traditionally important stakeholders such as capital providers continue to view economic growth as most important to sustainability, internal stakeholders such as employees view social improvements - equity, work-life balance, health, and safety, training - as the most important aspects of sustainability (Konrad et al., 2006). Considering gender diversity, there are a few key reasons why women on boards are expected to be attuned to a broader range of stakeholder demands on corporate resources.

First, stakeholder theory (Clarkson, 1995; Freeman, 1984) posits that a firm's sustainability is determined, in large part, by the extent to which it considers the interests of its stakeholding communities. Thus, the doctrine of stakeholder management directs corporate boards to pursue outcomes that optimize the results for all involved stakeholders rather than maximize the results for one stakeholder group (i.e., shareholders). However, addressing multiple stakeholder interests and demands requires a relational perspective and the ability to maintain positive relationships with those stakeholders (Hillman \& Keim, 2001). Women have been found to be more orientated towards supporting and maintaining relationships than men, and they more readily focus on the needs of others rather than on their own needs (Hater \& Bass, 1988; Hisrich \& Brush, 1984; Rosener, 1995). Women on boards would be expected to engage in and build better relations with stakeholders because of their greater focus on the needs of others, positioning firms not only to better understand the social demands of their constituent base, but also to avoid costly missteps with strategic decisions regarding sustainability. Such relational abilities are essential to sustainable strategy development (Konrad et al., 2006; Miles, Munilla, \& Darroch, 2006). Similarly, the work of Biggins (1999) suggests that because of women's orientation towards supporting and maintaining relationships, they understand and better represent the needs of all stakeholders. This orientation would be expected to aid in the formulation of strategy and in decisions made regarding policies of the firm, especially those related to social responsibilities.

Second, concern over how firms address social responsibility can influence product positioning. For example, in their study, Brown and Dacin (1997) found evidence to suggest that firms' ability to demonstrate social responsibility can positively influence consumer perceptions about product quality. Studies such as Brown and Dacin's (1997) suggest that understanding customers and their needs is vitally important to firms' ability to address sustainability. Given that 81 percent of all products and services are purchased by women (Hefferman, 2002), women on boards are likely to bring knowledge of consumer demands (Daily, Certo, \& Dalton, 1999). Thus, in the case of diversity on boards, evidence suggests that women may have a better understanding of consumer behavior, the needs of customers, and opportunities for companies in meeting those needs (Brennan \& McCafferty, 1997; Mattis, 1993; Natividad, 2005). As customers are a major stakeholder of any firm (Clarkson, 1995), women board members are expected to influence the social dimension of sustainability. Hence,

Hypothesis 2: There is a positive relationship between women on boards and the social responsiveness dimension of sustainability

\section{Possibility of limited gender-related influence on corporate sustainability}

While there are many attributes of women on boards that are expected to impact positively on 
sustainability, their influence might be limited. For example, a recent study brings into question the influence of women board members on environmental quality. Galbreath (2009b) assesses how 98 firms, in 10 countries, are responding to climate change (a key aspect of environmental quality). By studying a variety of board composition variables (e.g., director independence, board size, separation of CEO, and chair roles), he finds that the proportion of women on boards have no influence on how well firms are addressing climate change. The results of Galbreath's (2009b) study warrant further understanding as to why women on boards might be limited in their ability to influence decisions with respect to environmental quality.

A substantial amount of anecdotal evidence, and increasingly empirical data, suggests that corporations can benefit by appointing more women on boards. However, at the same time, women directors appear to face barriers including gender discrimination and stereotyping - that might restrict their ability to fully contribute to corporate strategy and oversight (Arfken et al., 2004; Catalyst, 2005; EOWA, 2008). Such discrimination and stereotyping is highlighted in a recent interview with board members conducted in Australia (EOWA, 2008), where male directors stated they tend to welcome women directors' input on so-called 'soft' issues, such as human resources, occupational health and safety, corporate donations, and ethics. Input from women on issues related to customer service and product development/direction was also welcomed by male board members. Conversely, the results of the Australian study suggest that men can limit the degree to which they favor women board member input. For example, men board members tended to accept other male members input on more technical issues, such as engineering, while discounting women director input (EOWA, 2008). This is likely to have an impact on firms' environmental quality.
Issues dealing with the natural environment, such as climate change, carbon emission reductions and environmental management systems (EMS) tend to be associated with hard science, technology and technical or engineering processes (e.g., Hart \& Ahuja, 1996; Klassen \& Whybark, 1999; Mann \& Jones, 2003; Mann, Bradley, \& Hughes, 1998; Sharma \& Henriques, 2005). With respect to these tendencies, in the boardroom, men directors are more likely than women directors to have degrees and backgrounds in technical disciplines, including science and engineering (Singh et al., 2008). Further, women directors tend to have stronger backgrounds in non-profit and community-based organizations, whereas men directors tend to have stronger backgrounds in traditional business corporations (Hillman, Cannella, \& Harris, 2002). Such differences could lead to selective perceptions with respect to sustainability issues addressed by the board. For example, following social impact theory (Latané \& Wolf, 1981; Maass \& Clark, 1984), the greater the decision-making experience in a functional area, the more that functional area is represented in the decision maker's perceptions.

Given that men on boards have more decisionmaking experience in issues related to science and engineering than women (Singh et al., 2008), I posit that they might be more comfortable accepting input from like decision makers (i.e., men), while discounting input from those (i.e., women) outside the decision-making domain. That is, men directors are likely to perceive that women directors have less experience in addressing issues related to the natural environment due to both their functional backgrounds and previous work experiences, resulting in sex-based biases or intentional stereotyping (cf. Beyer et al., 1997; Bilimoria \& Piderit, 1994; Eagly, JohannesenSchmidt, \& van Engen, 2003; Funder \& Ozer, 1983; Powell, Bagihole, \& Dainty, 2009; Schein, 1973). Such bias or stereotyping can lead to disproportionately less influence of the out-group (Maass \& Clark, 1984), thus, 
Hypothesis 3: There is no relationship between women on boards and the environmental quality dimension of sustainability

\section{Methods}

\section{Sample and approach}

The sample consisted of Australian Securities Exchange (ASX) 200 firms from 2004. I chose the year 2004 as this is the first year that the Australian Government's Equal Opportunity for Women in the Workplace Agency (EOWA) conducted research on women on boards in the ASX 200 sample (EOWA, 2004). Given that board structure is the putative cause and performance its effect (Westphal, 1999), and to address a proxy measure of sustainability given its longer-term nature, a 3-year lagged measure was used for the dependent variables, covering the years 2005-2007. I eliminated 41 firms who were acquired/merged, delisted, liquidated, or naturally replaced by the end of the financial year 2007. A further eight firms were excluded as outliers because their results were 20 standard deviations away from the mean on the ROE measurement. Therefore, the final sample consisted of 151 firms.

Of the 151 firms, 35 percent represent heavy industries such as resources, energy, transportation, and capital goods. Thirty seven percent represent services industries, such as media, finance, and health care. The rest of the sample (28 percent) consisted of a variety of industries, including consumer staples, telecommunications, and retailing. By industry, those with the largest mean percentage of women representation on the board include telecommunications (2 firms/22.6 percent female), insurance (5 firms/21.4 percent female), and media (11 firms/16.3 percent female). Industries with the lowest mean representation of women on the board include materials (31 firms/6.6 percent female), transportation ( 9 firms/5.6 percent female), and capital goods and energy (7 and 11 firms, respectively/ both 5 percent female). With respect to women representation on boards, a one-way ANOVA test revealed that differences across the 22 industries in the sample is modestly significant $(F=1.56$; $p=.06)$.

Regarding environmental and social aspects of sustainability, the difficulty of developing reliable proxies for such variables is well documented in the literature (see, for example, Ilinitch, Soderstrom, \& Thomas, 1998). For this study, in the absence of readily obtainable secondary sources to measure the degree of environmental quality and social responsiveness, content analysis of annual reports was used. There are four key reasons why the use of annual reports is appropriate for this study. First, annual reports are useful in the study of organizational behavior and strategy because they provide comparable sets of data and represent an account of a firm's activities (Arndt \& Bigelow, 2000; Bettman \& Weitz, 1983; Salancik \& Meindl, 1984), such as sustainability. Second, support for the use of annual reports in this study comes from the fact that existing research exploring issues related to sustainability have reliably used such reports (e.g., Cormier, Magnan, \& Van Velthoven, 2005; Maignan \& Ralston, 2002). Third, evidence suggests there is a correlation between discussion offered in annual reports on dimensions such as environmental quality, and objective measures of those dimensions (e.g., Clarkson, Li, Richardson, \& Vasvari, 2008; Patten, 2002). Lastly, although public material could be inflated, this is likely not realistic as companies can be held to their commitments (Krut \& Munis, 1998). Therefore, sufficient accuracy and transparency in the annual report was assumed.

\section{Dependent variables}

\section{Economic growth}

To measure economic growth, I used three variables: (1) return on equity (ROE), (2) return on assets (ROA); and (3) the market-to-book value of equity (M/B) (see Appendix A for a description 
of measurement). ROE and ROA were chosen because they reflect operating efficiency, financing choices for future growth, and how well firms are employing assets and funds invested by shareholders to generate returns. Quite simply, firms who do not consistently deliver positive returns on invested capital are unlikely to be sustainable economically. Because the $\mathrm{M} / \mathrm{B}$ hinges on growth prospects and the expected future performance of firms (Devers, Cannella, Reilly, \& Yoder, 2007; Rust, Lemon, \& Zeithaml, 2004), it also represents a good proxy of economic growth. All variables were measured for the years 2005-2007 and the 3-year average was computed for statistical tests. Data were obtained from Aspect Huntley's FinAnalysis, a secondary database covering publicly listed Australian firms.

\section{Environmental quality and social responsiveness}

In order to capture proxy measures designed to assess environmental and social dimensions, Williams (1999) was followed. Williams (1999) conducted extensive research to identify items that would optimally measure environmental and social dimensions. I constructed a set of items that most closely represented environmental quality and social responsiveness (e.g., Bansal, 2005; Konrad et al., 2006; Sharma, 2000; Sharma \& Henriques, 2005; Steurer et al., 2005). Measurement items are displayed in Appendix B. Although factor analysis of the items to assess convergent and discriminant validity would have been optimal, because of the use of a dichotomous ( 1 or 0 ) scale to score each item, 0 variance items prohibited this test.

Since I was interested in whether firms were demonstrating actions/activities that related to environmental quality and social responsiveness, a simple binary code indicating whether or not actions/ activities were discussed in a narrative was sufficient for this research (Westphal \& Zajac, 1998). For analysis of content, I followed Gamble, Hsu, Kite, and Radtke (1995) by determining the extent to which the narrative provided stakeholders with necessary information to assess current and future impacts of strategies consistent with environmental and social concerns. For environmental quality narrative, examples included 'greenhouse gas emissions were reduced by six percent' and 'the company purchases power that has been generated by alternative energy sources, including hydro-electric and windpower'. For social responsiveness narrative, examples included 'we made significant investments in employee training in 2005' and 'worker health was improved ... by achieving 26-percent reduction in incidence of occupational disease since FY2005'. In cases where no new or updated narratives on a given item (Appendix B) were provided in a subsequent year, they were not counted.

For scoring, a dichotomous scale (' 1 ' for presence of discussed item in a narrative, otherwise ' 0 ') was used so as to minimize subjectivity in the scoring process. Following Bansal (2005), firms were scored by summing the number of items discussed in a narrative for each dimension. The summed score was then divided by the total number of possible items for the overall dimension. Each year (20052007) was computed with the procedure and then the 3-year average calculated. Inter-rater reliability between two coders on a random sub-sample of 20 annual reports across all years revealed a $\pi$ of 0.814 , which was acceptable (Hackston \& Milne, 1996).

\section{Independent variables}

\section{Women on boards}

Following previous studies (e.g., Bonn, 2004), the proportion of women on boards was measured as the number of women relative to the total number of board members. Data for women on boards and total board size came from company annual reports, and Connect 4, an electronic database with coverage of boards of directors in Australia.

\section{Control variables}

Various proxy measures (such as total assets, total sales, and market capitalization) have been used to measure firm size, and there is no overwhelming theoretical or empirical evidence supporting the use of a particular measure. Since total assets and market capitalization have been used extensively 
to capture firm size, they were both included in this study (see Appendix A). Additional control variables included slack resources, outsider representation on the board, board size, and industry (see Appendix A for measurement). Slack resources have been found to affect how well firms address environmental and social responsibilities (Waddock \& Graves, 1997) and were measured by net profit. With respect to outside board members, studies indicate that they exhibit a greater concern for social responsibility than inside board members (Ibrahim \& Angelidis, 1995). Outside board membership was measured by the proportion of outsiders to insiders. Following Carter et al. (2003), board size was also controlled for and was measured by total number of board members. Lastly, firms in the sample represented 22 different industry sectors. Given the sample size of 151, including this many industry control variables would have used up too many degrees of freedom. Accordingly, based on Hassel, Nilsson, and Nyquist (2005), industries were collapsed into two different segments, either manufacturing (coded ' 1 ') or services (coded ' 0 '). Control variables were measured in 2004 with data obtained from FinAnalysis, annual reports, and Connect 4.

\section{RESULTS}

Table 2 reports the descriptive statistics and correlations for continuous variables used in the study. The mean (SD) proportion of women on boards is .09 (.12). The mean (SD) board size is 7.58 (2.05). The mean (SD) proportion outside (independent) directors is .81 (.15). The mean (SD) for total assets is AUS\$14,168 million (AUS\$51,163). The mean (SD) for net profit is AUS\$448 million (AUS\$1,087). The mean (SD) market capitalization is AUS\$5,848 million (AUS\$15,174). The mean (SD) ROE is 15.27 (10.59). For ROA, the mean (SD) is 8.24 (6.29). The mean (SD) M/B is 2.58 (2.10). The mean (SD) for the environmental quality score is .27 (.23). Lastly, for the social responsiveness score, the mean (SD) is .33 (.23).

\section{Initial test: Does critical mass matter?}

Following critical mass theory (Konrad et al., 2008), I decided to conduct an initial test to see if differences existed between firms with women on boards and those without, running a series of $t$ tests of differences in means. To reduce the possibility of a 'token' female in the comparison, firms were grouped into those that had no women on their boards and those that had two or more women on the board, resulting in a sample of 69 and 19 firms, respectively. The results are presented in Table 3. Firms who have two or more women board members have higher ROE (20.97 vs. 13.63), higher $\mathrm{M} / \mathrm{B}$ (3.49 vs. 2.29), higher market capitalizations $(\$ 15,061$ vs. $\$ 4,641)$, higher levels of revenue ( $\$ 8,549$ vs. $\$ 2,077$ ), higher net incomes (\$1,026 vs. \$266), and demonstrate higher social responsiveness (.48 vs. .27). No differences were found between the two groups on ROA ( 7.75 vs. 8.56$)$ and environmental quality (.25 vs. .24). The results offer some level of support for critical mass theory (Konrad et al., 2008) and suggest a potential link between women on boards and sustainability. However, the comparative results do not account systematically for the degree of relationship between the criterion variables and the weighted combination of the predictor variables. Thus, in the next section, main effects analysis and testing of the hypotheses is explored with regression analysis.

\section{Main effects: Regression analysis and hypotheses testing}

To test the hypotheses, hierarchical regression analysis was used. All control variables were entered in the first step and, in the second step, the variable, proportion of women on boards, was entered. Changes in $R^{2}$ values were used as the test of significance to confirm or reject hypotheses. Prior to hypothesis testing, multicollinearity was assessed by calculating variance inflation factors (VIF) and tolerance values. VIF ranged from a low of 1.043 to a high of 1.595. Tolerance values were no lower than 0.627 . Given that VIF values above 10 and 
Gender-related influences on corporate sustainability of women board directors

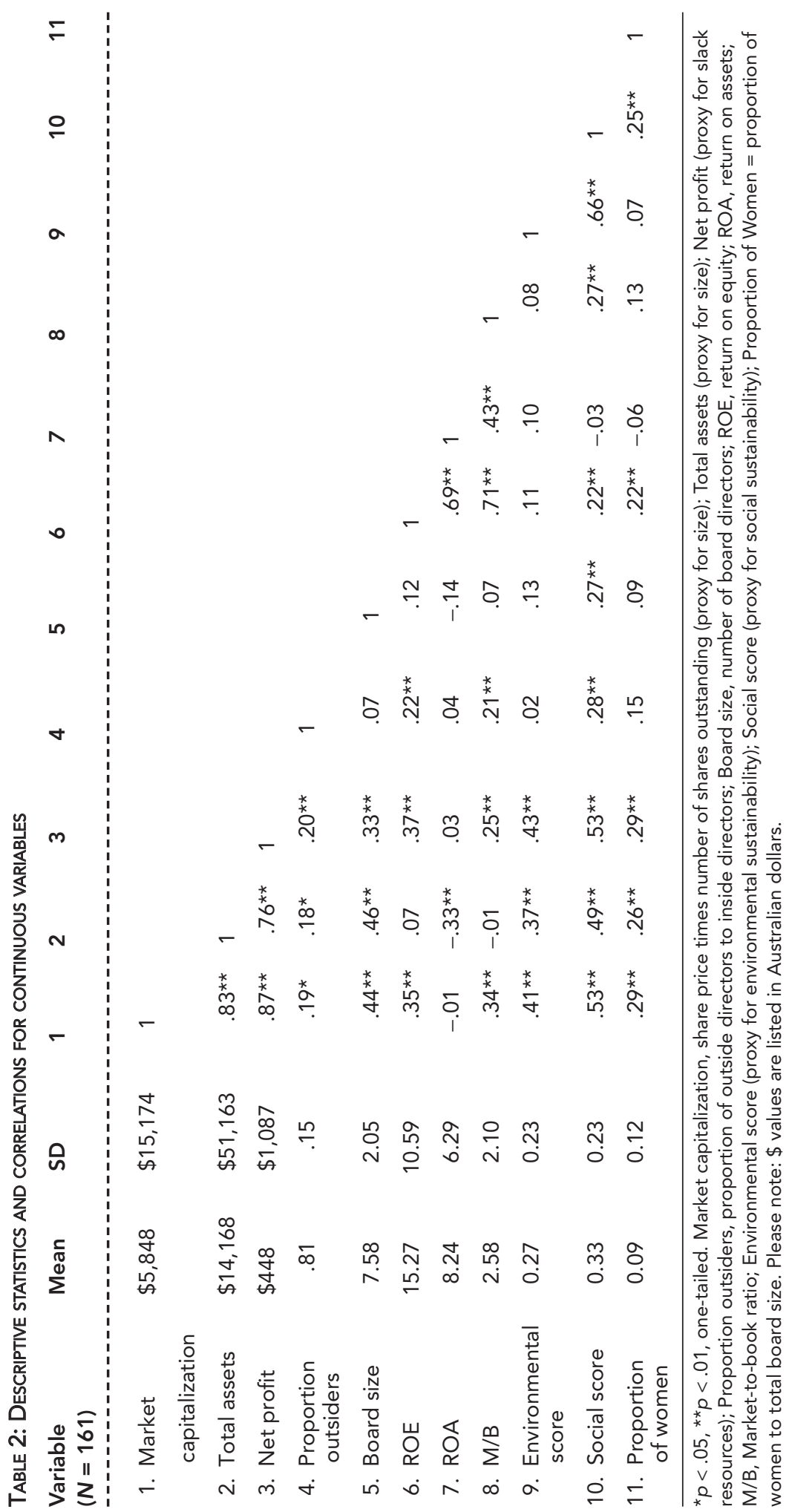


Jeremy Galbreath

TABLE 3: COMPARISON RESULTS OF WOMEN ON BOARDS

\begin{tabular}{lcccc} 
Variable & $\begin{array}{c}\text { Firms with no } \\
\text { women }(\mathbf{N}=69)\end{array}$ & $\begin{array}{c}\text { Firms with two or } \\
\text { more women }(\mathbf{N}=19)\end{array}$ & $\boldsymbol{t}$ statistics & $\boldsymbol{p}$ value \\
ROE & 13.63 & 20.97 & 2.875 & .005 \\
ROA & 8.56 & 7.75 & .456 & .650 \\
M/B & 2.29 & 3.49 & 2.869 & .005 \\
Market capitalization & $\$ 4,641$ & $\$ 15,061$ & 2.717 & .008 \\
Revenue & $\$ 2,077$ & $\$ 8,549$ & 3.714 & .000 \\
Net income & $\$ 266$ & $\$ 1,026$ & 2.934 & .004 \\
Environmental quality & .25 & .24 & .183 & .855 \\
Social responsiveness & .27 & .48 & 3.940 & .000 \\
\hline
\end{tabular}

TABLE 4: RESULTS FOR THE ECONOMIC DIMENSION OF SUSTAINABILITY

\begin{tabular}{|c|c|c|c|c|c|c|}
\hline \multirow[b]{2}{*}{ Independent variables } & \multicolumn{6}{|c|}{ Dependent variables } \\
\hline & Step 1 & Step 2 & Step 1 & Step 2 & Step 1 & Step 2 \\
\hline Industry dummy & $-.14^{+}$ & -.13 & .04 & .04 & $-.20 * \star$ & $-.19 * \star$ \\
\hline Market capitalization & .15 & .14 & -.15 & .15 & $.31^{\star *}$ & $.30 \star \star$ \\
\hline Logarithm total assets & $-.33^{\star \star \star}$ & $-.40^{\star \star \star}$ & $-.65^{\star \star \star}$ & $-.68^{\star \star \star}$ & $-.37^{\star \star \star}$ & 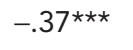 \\
\hline Net profit & $.31^{\star *}$ & $.31^{\star *}$ & $.30^{\star *}$ & $.30 \star \star$ & .05 & .05 \\
\hline Proportion outsiders & -.11 & .11 & .09 & .09 & .12 & .12 \\
\hline Board size & -.02 & .07 & -.04 & -.00 & .00 & .09 \\
\hline Proportion women & & $.18^{\star \star}$ & & .08 & & $.19 \star \star$ \\
\hline$R^{2}$ & -.15 & .17 & .26 & .27 & .15 & .18 \\
\hline$\Delta R^{2}$ & & $.02^{\star \star}$ & & .01 & & $.03^{\star *}$ \\
\hline$F$ & $4.048^{\star \star *}$ & $4.153^{\star \star \star *}$ & $8.509^{* * *}$ & $7.421^{\star \star}$ & $4.341^{\star *}$ & 4.450 *** \\
\hline
\end{tabular}

${ }^{\dagger} p<0.10,{ }^{*} p<0.05,{ }^{* *} p<0.01,{ }^{* *} p<0.001$.

tolerance values close to 0 are considered problematic (Hair, Anderson, Tatham, \& Black, 1995), the results suggested that multicollinearity was likely not a problem in this sample.

Tables 4 and 5 present the results of the regression analysis. Based on the results, there appears to be some level of support for a positive relationship between women on boards and sustainability. As for economic performance (Table 4), for ROE the $\Delta R^{2}$ is significant $\left(\Delta R^{2}=.02 ; p=.042\right)$. For ROA, the $\Delta R^{2}$ change is not significant $\left(\Delta R^{2}=.005\right.$; $p=.339)$. The non-significant finding could be a result of a fairly high correlation between ROE and ROA (.69), which are two widely used accounting variables to measure economic outcomes. As for the $\mathrm{M} / \mathrm{B}$ ratio, the $\Delta R^{2}$ is significant $\left(\Delta R^{2}=.03 ; p=.037\right)$. Given that two of the three economic growth variables produced a significant and positive result, the findings suggest support for Hypothesis 1. Hypothesis 2 explores the link between women on boards and social responsiveness. The $\Delta R^{2}$ is positive and significant $\left(\Delta R^{2}=.02\right.$; 
TABLE 5: RESULTS FOR THE ENVIRONMENTAL AND SOCIAL DIMENSIONS OF SUSTAINABILITY

\begin{tabular}{|c|c|c|c|c|}
\hline \multirow[b]{2}{*}{ Independent variables } & \multicolumn{2}{|c|}{ Environmental } & ariables & Social \\
\hline & Step 1 & Step 2 & Step 1 & Step 2 \\
\hline Industry dummy & .01 & .01 & $-.17^{\star \star}$ & $-.17^{\star \star}$ \\
\hline Market capitalization & .08 & .08 & .14 & .14 \\
\hline Logarithm total assets & $.29 * \star \star$ & $.30^{\star \star}$ & $.34^{\star \star \star}$ & $.29 * \star$ \\
\hline Net profits & .03 & .03 & .06 & .05 \\
\hline Proportion outsiders & .02 & .02 & $.18^{\star \star}$ & $.18^{\star \star}$ \\
\hline Board size & -.05 & -.07 & -.04 & .02 \\
\hline Proportion women & & -.03 & & $.14^{\star}$ \\
\hline$R^{2}$ & .12 & .12 & .33 & .35 \\
\hline$\Delta R^{2}$ & & .00 & & $.02^{*}$ \\
\hline$F$ & $2.999 * \star \star$ & $2.568^{\star \star}$ & $11.377^{\star \star \star}$ & $10.365^{\star \star \star}$ \\
\hline
\end{tabular}

$p=.076)$, suggesting support for the hypothesis (Table 5). As can be seen in Table 5, women on boards are not statistically associated with environmental quality $\left(\Delta R^{2}=.001 ; p=.699\right)$. Thus, Hypothesis 3 also finds support.

The control variables are found to be linked with corporate sustainability. With the exception of one of the economic performance measures (ROA) and environmental quality, the industry dummy variable is significant and negative. This finding might suggest that in the Australian context, some industry sectors are struggling to meet their commitments to, or have higher demands for, sustainability, which are difficult to meet. Market capitalization is positive and significantly associated only with the $\mathrm{M} / \mathrm{B}$ ratio, which was expected. Total assets are significantly but negatively associated with economic performance variables, yet significantly and positively associated with environmental quality and social responsiveness. This finding seems contradictory. One possible explanation might be that as firms attempt to commit their asset bases to improve environmental and social dimensions, there is an opportunity cost to efforts focused purely on economic performance. Net profits are positively associated with ROE and ROA, suggesting that slack resources are likely important in generating an adequate returns to investors. Outside board representation is significantly and positively associated with social responsiveness. This finding confirms previous studies (e.g., Ibrahim \& Angelidis, 1995), demonstrating that outsiders on the board are linked with corporate sustainability. Lastly, board size is non-significant across all dependent variables.

\section{DISCUSSION AND IMPLICATIONS}

Overall, the findings of this study suggest some level of support that gender diversity on corporate boards is positively linked with sustainability. Women on boards were positively linked with both economic growth and social responsiveness, which supported Hypotheses 1 and 2. Alternatively, the proportion of women on boards had a non-significant relationship with environmental quality, which was the predicted association in Hypothesis 3. With respect to the first two hypotheses, the evidence would suggest that by increasing gender diversity on boards, firms 
may be able to improve stakeholder relationships and increase accountability and ethical conduct (cf. Arfken et al., 2004), with a resultant positive impact on both economic growth and social responsiveness. However, women on boards are likely to encounter some resistance in decisionmaking processes that could limit their influence on sustainable outcomes. For example, sex-based biases or stereotyping by male directors might be inhibiting women directors' voice on environmental issues in this sample, which would confirm the view of previous research (e.g., Bilimoria \& Piderit, 1994; Hefferman, 2002). Thus, based on the findings, a few key implications are put forth.

First, corporations are under immense pressure to demonstrate responsible governance. In an effort to meet this commitment, various guidelines have been recommended, such as ensuring a majority of independent directors on the board, transparency in remuneration policies and splitting CEO, and chairperson roles (Zattoni \& Cuomo, 2009). However, increasing the number of women on boards might also be a strategy for improving the oversight of corporations today. For example, shareholders and investors are concerned about a firm's duty of care, accountability, and transparency. Duty of care, accountability, and transparency are increasingly reflective of effective or so-called 'good' corporate governance (Adams \& Ferreira, 2009). Specifically, as firms seek to increase their legitimacy in society, integrity, and ethical standards at the board level are highly important (Arfken et al., 2004; Brown et al., 2002; Flynn \& Adams, 2004). Evidence suggests that women's moral orientation and ethical standards are higher than men's (Betz, O'Connell, \& Shepard, 1989), that they demonstrate a more effective monitoring role at the board level than men (Adams \& Ferreira, 2009) and that as board directors they are more likely than men to provide oversight of ethical conduct in the firms they serve (Brown \& Brown, 2001). The findings of this study suggest that increasing gender diversity on boards might be a means to help ensure that shareholder funds are not misappropriated, resulting in better economic performance.
Second, women on boards are likely to play a valuable role in ensuring firms address sustainability by establishing relationships with a broad stakeholder base. However, demands of stakeholders can be different and conflicting (Mitchell et al., 1997), complicating decision-making processes at the board level. Offering some support for gender diversity, women are particularly adept at problem-solving, are very skilled at dealing with complexity and ambiguity, and demonstrate a strong orientation towards supporting and maintaining relationships (Hisrich \& Brush, 1984; Rosener, 1995). Hence, women in upper echelon positions, such as corporate boards, might assist firms to effectively traverse the complexities of stakeholder demands for sustainability. That women on boards were positively related to social responsiveness in this study suggests that they might be ensuring that commitments to stakeholders beyond shareholders are not being overlooked, while ensuring that decision making takes into account the alternative demands that various stakeholders impose on strategy.

Lastly, differences between men and women should be embraced in the board room. Admittedly, women face an extremely difficult pathway to reach the corporate boardroom (Desvaux, Devillard-Hoellinger, \& Baumgarten, 2007; EOWA, 2008; Singh et al., 2008); however, where critical mass is achieved (Desvaux et al., 2007; Konrad et al., 2008), their impact can be substantial. In the case of sustainability, this is a very complex paradigm facing corporations today and requires decision making at the highest level of the corporation (Benn \& Dunphy, 2007). Hence, following gender diversity perspectives, an implication of the present study suggests that in addition to a focus of research on why women have difficulty in obtaining board of research level positions, attention could also be focused on better understanding how differences between men and women directors positively interact to affect sustainable outcomes. That is, an implication of this study suggests that as men and women bring different skills and focus to bear on corporate 
problems, these differences might actually help ensure a balanced approach in response to economic, environmental, and social response.

\section{CONCLUSION, LIMITATIONS, AND DIRECTIONS FOR FUTURE RESEARCH}

Firms are increasingly confronted with managing and responding to expectations of a society alerted to the environmental and social risks associated with economic development (Davis \& Stephenson, 2006; Parnell, 2008). Evidence does suggest that society more than ever is demanding that firms move beyond narrow, money-making self-interest by focusing significant attention and resources on social and environmental activities (Oppenheim, Bonini, Bielak, Kehm, \& Lacy, 2007). Further, firms are recognizing that to maintain their competitive positions and legitimacy in society, addressing social and environmental issues is paramount (Porter \& Kramer, 2006; Porter \& Reinhardt, 2007). Sustainability, then, is a substantial corporate issue and one that should be addressed at the board level (Aguilera, Williams, Conley, \& Rupp, 2006; Ayuso \& Argandoña, 2007; Benn \& Dunphy, 2007; Clarke, 2007; Jamali et al., 2008). This study finds that women on boards might potentially be a positive influence on sustainability, although not across all dimensions. Thus, the present study adds needed insight into a primary question in governance research, the question of whether gender diversity at the board level affects firm outcomes (Adams \& Ferreira, 2009; Carter et al., 2003).

Several limitations of this study are recognized. First, the sample came from firms in Australia and, as such, generalizability may be limited. However, because firms in Australia tend to lag other developed countries in percentage of women directors (EOWA, 2008) the current sample is an attractive opportunity for study, with the results representing important insight. Second, the sample included the top 200 firms on the Australian Stock Exchange. The results might not be representative of smaller or private firms operating in Australia. Third, while the results suggest that women on boards are positively linked to sustainability, firms who take sustainability seriously could potentially be those that are likely to appointment more women to their boards. However, the mean percentage of women on boards was only nine percent in this sample - low compared to other industrialized nations - suggesting that firms in Australia are not readily appointing women to boards. Lastly, use of annual reports is a potential limitation. 'Spin' could be present as a means to inflate a given firm's demonstration of sustainability, particularly on the environmental and social dimensions. Yet, according to Clarkson et al. (2008) and Patten (2002), there is a strong correlation between information offered in annual reports on dimensions such as environmental quality, and objective measures of those dimensions. Thus, using content analysis of annual reports in this study is likely not a significant problem.

By examining the relationship between women on boards and sustainability, this study provides a roadmap for more focused studies' examination of these relationships. Future studies could explore, for example, whether attendance at board meetings by women is generally higher than men, and whether higher attendance correlates to positive decisions regarding policies addressing sustainability. Another key area of future study is examining the types of committees women are appointed to. More specifically, future research could longitudinally investigate if environmental quality of firms improves as more women are appointed to committees that address issues such as climate change. Another focus could be broader aspects of diversity. This study focused specifically on gender diversity. Future studies could explore other aspects of diversity at the board level, such as ethnic background, to determine relationships with sustainability.

\section{References}

Adams, R., \& Ferreira, D. (2009). Women in the boardroom and their impact on governance and performance. Journal of Financial Economics, 94, 291-309.

Aguilera, R. V., Rupp, D. E., Williams, C. A., \& Ganapathi, J. (2007). Putting the S back in corporate social responsibility: A multi-level theory 
of social change in organizations. Academy of Management Review, 32, 836-863.

Aguilera, R. V., Williams, C. A., Conley, J. M., \& Rupp, D. E. (2006). Corporate governance and social responsibility: A comparative analysis of the UK and the US. Corporate Governance: An International Review, 14, 147-158.

Arfken, D., Bellar, S., \& Helms, M. (2004). The ultimate glass ceiling revisited: The presence of women on corporate boards. Journal of Business Ethics, 50, 177-186.

Arndt, M., \& Bigelow, B. (2000). Presenting structural innovation in an institutional environment: Hospitals' use of impression management. Administrative Science Quarterly, 45, 494-522.

Ayuso, S., \& Argandoña, A. (2007). Responsible corporate governance: Towards a stakeholder board of directors? Working Paper No. 701, Barcelona: IESE Business School, University of Navarra.

Bacon, B. (2007). The new paradigm of business in society: A purpose beyond product. Melbourne: Paper presented at Business Council of Australia.

Bansal, P. (2001). Building competitive advantage and managing risk through sustainable development. Ivey Business Journal, 66, 47-52.

Bansal, P. (2005). Evolving sustainability: A longitudinal study of corporate sustainable development. Strategic Management Journal, 26, 197-218.

Barney, J. B., \& Hansen, M. H. (1994). Trustworthiness as a source of competitive advantage. Strategic Management Journal, 15(Special Issue), 175-190.

Benn, S., \& Dunphy, D. (Eds.). (2007). Corporate governance and sustainability. London: Routledge.

Bettman, J. R., \& Weitz, B. A. (1983). Attributions in the board room: Causal reasoning in corporate annual reports. Administrative Science Quarterly, 28, 165-183.

Betz, M., O’Connell, L., \& Shepard, J. M. (1989). Gender differences in proclivity for unethical behaviour. Journal of Business Ethics, 8 , 321-342.

Beyer, J. M., Chattopadhyay, P., George, E., Glick, W. H., Ogilvie, D., \& Pugliese, D. (1997). The selective perceptions of managers revisited. Academy of Management Journal, 40, 716-737.
Bhimani, A., \& Soonawalla, K. (2005). From conformance to performance: The corporate responsibilities continuum. Journal of Accounting and Public Policy, 24, 165-174.

Biggins, J. V. (1999). Making board diversity work. Corporate Board, 20, 11-17.

Bilimoria, D., \& Piderit, S. K. (1994). Board committee membership: Effects of sex-based bias. Academy of Management Journal, 37, 1453-1477.

Bonn, I. (2004). Board structure and firm performance: Evidence from Australia. Journal of the Australian and New Zealand Academy of Management, 10, 14-24.

Brennan, N., \& McCafferty, J. (1997). Corporate governance practices in Irish companies. Irish Journal of Management, 18, 116-135.

Brown, D. A. H., \& Brown, D. L. (2001). Canadian directorship practices 2001. Ottawa: The Conference Board of Canada.

Brown, D. A. H., Brown, D. L., \& Anastasopoulos, V. (2002). Women on boards: Not just the right thing...but the "bright" thing. Ottawa: The Conference Board of Canada.

Brown, T. J., \& Dacin, P. A. (1997). The company and the product: Corporate associations and consumer product responses. Journal of Marketing, 61, 68-84.

Carroll, A. B. (1979). A three-dimensional conceptual model of corporate performance. Academy of Management Review, 4, 497-505.

Carter, D. A., Simkins, B. J., \& Simpson, W. G. (2003). Corporate governance, board diversity and firm value. The Financial Review, 38, $33-53$.

Catalyst (2004). The bottom line: Connecting corporate performance and gender diversity. New York: Catalyst.

Catalyst (2005). Women 'take care', men 'take charge': Stereotyping of US business leaders exposed. New York: Catalyst.

Clarke, T. (2007). The evolution of director's duties: Bridging the divide between corporate governance and corporate social responsibility. Journal of General Management, 32, 79-105.

Clarkson, M. B. E. (1995). A stakeholder framework for analyzing and evaluating corporate social performance. Academy of Management Review, 20, 92-117. 
Clarkson, P. M., Li, Y., Richardson, G. D., \& Vasvari, F. P. (2008). Revisiting the relation between environmental performance and environmental disclosure an empirical analysis. Accounting, Organisations and Society, 33, 303-327.

Conner, K. R. (1991). A historical comparison of resource-based theory and five schools of thought with industrial organization economics: Do we have a new theory of the firm? Journal of Management 17(Special Issue), 121-154.

Cormier, D., Magnan, M., \& Van Velthoven, B. (2005). Environmental disclosure quality in large German companies: Economic incentives, public pressures or institutional conditions? European Accounting Review, 14, 3-39.

Daily, C. M., Certo, S. T., \& Dalton, D. R. (1999). A decade of corporate women: Some progress in the boardroom, none in the executive suite. Strategic Management Journal, 20, 93-100.

Davis, I., \& Stephenson, E. (2006). Ten trends to watch in 2006. The McKinsey Quarterly: The Online Journal of McKinsey \& Co. Available at http://www.bmacewen.com/blog/pdf/ McKinsey.2006.January.TenTrends.pdf de Luis-Carnicer, P., Martinez-Sánchez, A., \& Pérez-Pérez, M. (2008). Gender diversity in management: Curvilinear relationships to reconcile findings. Gender in Management: An International Journal, 23, 583-597.

Desvaux, G., Devillard-Hoellinger, S., \& Baumgarten, P. (2007). Women matter: Gender diversity, a corporate performance driver. Paris: McKinsey \& Company.

Devers, C. E., Cannella, Jr., A. A., Reilly, G. P., \& Yoder, M. E. (2007). Executive compensation: A multidisciplinary review and recent developments. Journal of Management, 33, 1016-1072.

Dobbin, F., \& Sutton, R. C. (1998). The strength of a weak state: The rights movement and the rise of the human resources management divisions. American Journal of Sociology, 104, 441-476.

Doering, D. S., Cassara, A., Layke, C., Ranganathan, J., Revenga, C., Tunstall, D., \& Vanasselt, W. (2002). Tomorrow's markets: Global trends and their implications for business. Baltimore, MD: World Resources Institute.

Donaldson, T., \& Dunfee, T. W. (1994). Toward a unified conception of business ethics: Integrated social contract theory. Academy of Management Review, 19, 252-284.

Eagly, A. H., Johannesen-Schmidt, M. C., \& van Engen, M. (2003). Transformational, transactional and laissez-faire leadership styles: A meta-analysis comparing women and men. Psychological Bulletin, 129, 569-591.

Elkington, J. (1997). Cannibals with forks: The triple bottom line of the 21st century business. Oxford: Capstone Publishing.

EOWA (2004). 2004 EOWA Australian census of women in leadership. Canberra: Equal Opportunity for Women in the Workplace Agency.

EOWA (2008). A gender in the boardroom. Canberra: Equal Opportunity for Women in the Workplace Agency.

Fama, E. F. (1980). Agency problems and the theory of the firm. Journal of Political Economy, $88,288-307$.

Fama, E. F., \& Jensen, M. C. (1983a). Agency problems and residual claims. Journal of Law and Economics, 26, 327-350.

Fama, E. F., \& Jensen, M. C. (1983b). Separation of ownership and control. Journal of Law and Economics, 26, 301-325.

Flynn, P., \& Adams, S. (2004). Changes will bring more women to boards. Financial Executive, 20, 32-35.

Francoeur, C., Labelle, R., \& Sinclair-Desgagné, B. (2008). Gender diversity in corporate governance and top management. Journal of Business Ethics, 81, 83-95.

Freeman, R. E. (1984). Strategic management: A stakeholder approach. Oxford: Blackwell.

Funder, D. C., \& Ozer, D. J. (1983). Behaviour as a function of situations. Journal of Personality and Social Psychology, 44, 107-112.

Galbreath, J. (2009a). Sustainable development in business: A strategic view. Working paper. Perth: Graduate School of Business, Curtin University.

Galbreath, J. (2009b). Corporate governance practices that address climate change: An exploratory study. Business Strategy and the Environment, 19, 335-350.

Gamble, G., Hsu, K., Kite, D., \& Radtke, R. (1995). Environmental disclosures in annual reports and 10K's: An examination. Accounting Horizons, 9, 34-54. 
Hackston, D., \& Milne, J. J. (1996). Some determinants of social and environmental disclosures in New Zealand companies. Accounting, Auditing \& Accountability Journal, 9, 77-108.

Hair, J. F., Jr., Anderson, R. E., Tatham, R. L., \& Black, W. C. (1995). Multivariate data analysis. New York: Macmillan.

Hart, S. L. (1995). A natural-resource-based view of the firm. Academy of Management Journal, 37, 986-1014.

Hart, S. L., \& Ahuja, G. (1996). Does it pay to be green? An empirical study of the relationship between emission reduction and firm performance. Business Strategy and the Environment, 5, 30-37.

Hart, S. L., \& Milstein, M. B. (2003). Creating sustainable value. Academy of Management Executive, 17, 56-69.

Hassel, L., Nilsson, H., \& Nyquist, S. (2005). The value relevance of environmental performance. European Accounting Review, 14, 41-61.

Hater, J. J., \& Bass, B. M. (1988). 'Superiors' evaluations and subordinates' perceptions of transformational and transactional leadership. Journal of Applied Psychology, 73, 695-702.

Hefferman, M. (2002). Exhibit A: The female CEO. Fast Company, 61, 58-66.

Henderson, D. (2005). The role of business in the world of today. Journal of Corporate Citizenship, 17, 30-32.

Hendry, K., \& Kiel, G. C. (2004). The role of the board in firm strategy: Integrating agency and organisational control perspectives. Corporate Governance: An International Review, 12, 500-520.

Hillman, A. J., Cannella, A. A. Jr., \& Harris, I. C. (2002). Women and racial minorities in the boardroom: How do directors differ? Journal of Management, 28, 747-763.

Hillman, A. J., \& Keim, G. D. (2001). Shareholder value, stakeholder management, and social issues: What's the bottom line? Strategic Management Journal, 22, 125-139.

Hillman, A. J., Keim, G. D., \& Luce, R. A. (2001). Board composition and stakeholder performance: Do stakeholder directors make a difference? Business and Society, 40, 295-314.
Hisrich, R. D., \& Brush, C. (1984). The woman entrepreneur: Management skills and business problems. Journal of Small Business Management, 22, 30-37.

Holliday, C. O. J., Schmidheiny, S., \& Watts, S. P. (2002). Walking the talk: The business case for sustainable development. Geneva: World Business Council for Sustainable Development.

Hosmer, L. T. (1995). Trust: The connecting link between organization theory and philosophical ethics. Academy of Management Review, 20, 379-403.

Ibrahim, N., \& Angelidis, J. (1995). The corporate social responsiveness orientation of board members. Journal of Business Ethics, 14, 405-410.

Ilinitch, A., Soderstrom, N., \& Thomas, T. (1998). Measuring corporate environmental performance. Journal of Accounting and Public Policy, 17, 387-408.

Jamali, D., Safieddine, A. M., \& Rabbath, M. (2008). Corporate governance and corporate social responsibility synergies and interrelationships. Corporate Governance: An International Review, 16, 443-459.

Jehn, K. A. (1995). A multimethod examination of the benefits and detriments of intragroup conflict. Administrative Science Quarterly, 40, 256-282.

Jehn, K. A., Northcraft, G. B., \& Neale, M. A. (1999). Why differences make a difference: A field study of diversity, conflict, and performance in workgroups. Administrative Science Quarterly, 44, 741-763.

Jensen, M. C. (1986). Agency costs of free cash flow, corporate finance and takeovers. American Economic Review, 76, 323-329.

Jensen, M. C., \& Meckling, W. H. (1976). Theory of the firm: Managerial behaviour, agency costs and ownership structure. Journal of Finance, 3, 305-350.

Kang, H., Cheng, M., \& Gray, S. J. (2007). Corporate governance and board composition: Diversity and independence of Australian boards. Corporate Governance: An International Review, 15, 194-207.

Klassen, R. D., \& Whybark, D. (1999). The impact of environmental technologies on manufacturing performance. Academy of Management Journal, 42, 599-615. 
Konrad, A., Kramer, V., \& Erkut, S. (2008). Critical mass: The impact of three or more women, on corporate boards. Organizational Dynamics, 37, 145-167.

Konrad, A., Steurer, R., Langer, M. E., \& Martinuzzi, A. (2006). Empirical findings on business-society relations in Europe. Journal of Business Ethics, 63, 89-105.

Krut, R., \& Munis, K. (1998). Sustainable industrial development: Benchmarking environmental policies and reports. Greener Management International, 21, 88-98.

Latané, B., \& Wolf, S. (1981). The social impact of majorities and minorities. Psychological Review, 88, 438-53.

Lynall, M. D., Golden, B. R., \& Hillman, A. J. (2003). Board composition from adolescence to maturity: A multitheoretic view. Academy of Management Review, 28, 416-431.

Maass, A., \& Clark, R. D. III (1984). Hidden impact of minorities: Fifteen years of minority influence research. Psychological Bulletin, 95, 428-450.

Mahon, J. F., \& Waddock, S. A. (1992). Strategic issues management: An integration of issue life cycle perspectives. Business and Society, 31, 19-33.

Maignan, I., \& Ralston, D. A. (2002). Corporate social responsibility in Europe and the U.S.: Insights from businesses' self-presentations. Journal of International Business Studies, 33, 497-514.

Mann, M. E., Bradley, R. S., \& Hughes, M. K. (1998). Global-scale temperature patterns and climate forcing over the past six centuries. Nature, 392, 779-787.

Mann, M. E., \& Jones, P. D. (2003). Global surface temperatures over the past two millennia. Geophysical Research Letters, 30, CLM 5-1-CLM 5-4.

Mattis, M. (1993). Women directors: Progress and opportunities for the future. Business in the Contemporary World, 5, 140-156.

Mercer Investment Consulting (2006). 2006 fearless forecast. New York: Mercer Investment Consulting.

Miles, M. P., Munilla, L. S., \& Darroch, J. (2006). The role of strategic conversations with stakeholders in the formation of corporate social responsibility strategy. Journal of Business Ethics 69, 195-205.
Miller, T., \& del Carmen Triana, M. (2009). Demographic diversity in the boardroom: Mediators of the board diversity-firm performance relationship. Journal of Management Studies, 46, 755-786.

Mitchell, R., Agle, B., \& Wood, D. (1997). Toward a theory of stakeholder identification and salience: Defining the principle of who and what really counts. Academy of Management Review, 22, 853-886.

Mizik, N., \& Jacobson, R. (2003). Trading off between value creation and value appropriation: The financial implications of shifts in strategic emphasis. Journal of Marketing, 67, 63-76.

Montiel, I. (2008). Corporate social responsibility and corporate sustainability. Organisation \& Management, 21, 245-269.

Natividad, I. (2005). Women directors and the global company. Directors Monthly, March $13-15$.

Noreen, E. (1988). The economics of ethics: A new perspective on agency theory. Accounting Organisations and Society, 13, 359-369.

Oppenheim, J., Bonini, S., Bielak, D., Kehm, T., \& Lacy, P. (2007). Shaping the new rules of competition: UN global compact participant mirror. New York: McKinsey \& Company.

Parnell, J. A. (2008). Sustainable strategic management: Construct, parameters, research directions. International Journal of Sustainable Strategic Management, 1, 35-45.

Patten, D. M. (2002). The relation between environmental performance and environmental disclosure: A research note. Accounting, Organisations and Society, 27, 763-773.

Porter, M. E. (1985). Competitive advantage. New York: The Free Press.

Porter, M. E., \& Kramer, M. R. (2006). Strategy and society: The link between competitive advantage and corporate social responsibility. Harvard Business Review, 84, 78-92.

Porter, M. E., \& Reinhardt, F. L. (2007). A strategic approach to climate. Harvard Business Review, 85, 22-23, 26.

Powell, A., Bagihole, B., \& Dainty, A. (2009). How women engineers do and undo gender: 
Consequences for gender equality. Gender, Work and Organisation, 16, 411-428.

Ricart, J. E., Rodríguez, M. A., \& Sánchez, P. (2005). Sustainability in the boardroom: An empirical examination of Dow Jones sustainability world index leaders. Corporate Governance: The International Journal of Business in Society, 5, 24-41.

Rose, C. (2007). Does female board representation influence firm performance? The Danish evidence. Corporate Governance: An International Review, 15, 404-413.

Rosener, J. B. (1995). America's competitive secret: Utilizing women as a management strategy. New York: Oxford University Press.

Russo, M. V., \& Fouts, P. A. (1997). A resourcebased perspective on corporate environmental performance and profitability. Academy of Management Journal, 40, 534-559.

Rust, R., Lemon, K., \& Zeithaml, V. A. (2004). Return on marketing: Using customer equity to focus marketing strategy. Journal of Marketing, $68,109-124$.

Salancik, G. R., \& Meindl, J. R. (1984). Corporate attributions as strategic illusions of management control. Administrative Science Quarterly, 29, 238-254.

Schein, V. E. (1973). The relationship between sex role stereotypes and requisite management characteristic. Journal of Applied Psychology, 57, 95-105.

Schmidheiny, S. (1992). Changing course: A global business perspective on development and the environment. Cambridge, MA: MIT Press.

Sharma, S. (2000). Managerial interpretations and organisational context as predictors of corporate choice of environmental strategy. Academy of Management Journal, 43, 681-697.

Sharma, S., \& Henriques, I. (2005). Stakeholder influences on sustainability practices in the Canadian forest products industry. Strategic Management Journal, 26, 159-180.

Singh, V., Terjesen, S., \& Vinnicombe, S. (2008). Newly appointed directors in the boardroom: How do women and men differ? European Management Journal, 26, 48-58.

Steurer, R., Langer, M. E., Konrad, A., \& Martinuzzi, A. (2005). Corporations, stakeholders and sustainable development I: A theoretical exploration of business-society relations. Journal of Business Ethics, 61, 263-281.

Stranislaw, J. A. (2007). Climate change and energy security: The future is now. New York: Deloitte Touche Tohmatsu.

Tirole, J. (2001). Corporate governance. Econometrica, 69, 1-35.

Victoria López, M., Garcia, A., \& Rodriguez, L. (2007). Sustainable development and corporate performance: A study based on the Dow Jones sustainability index. Journal of Business Ethics, 75, 285-300.

Waddock, S. A., \& Graves, S. B. (1997). The corporate social performance-financial performance link. Strategic Management Journal, 18, 303-319.

WCED (1987). Our common future. Oxford: Oxford University Press.

Westphal, J. D. (1999). Collaboration in the boardroom: The consequences of social ties in the CEO/board relationship. Academy of Management Journal, 42, 7-24.

Westphal, J. D., \& Zajac, E. J. (1998). The symbolic management of stockholders: Corporate governance reforms and shareholder reactions. Administrative Science Quarterly, 43, 127-153.

Williams, S. L. M. (1999). Voluntary environmental and social accounting disclosure practices in the Asia-Pacific region: An international empirical test of political economy theory. The Journal of International Accounting, 34, 1-30.

Williamson, O. E. (1975). Markets and hierarchies: Analysis and antitrust implications. New York: The Free Press.

Williamson, O. E. (1985). The economic institutions of capitalism. New York: The Free Press.

Wilson, M., \& Lombardi, R. (2001). Globalization and its discontents. Ivey Business Journal, 66, 69-72.

Zattoni, A., \& Cuomo, F. (2009). How independent, competent and incentivized should non-executive directors be? An empirical investigation of good governance codes. British Journal of Management, 21, 63-79.

Received 11 November 2009 Accepted 17 June 2010 


\section{Appendix A: MeAsurement of VARIABles}

Variable

Return on equity (ROE)

Return on assets (ROA)

Market-to-book ratio (M/B)

Total assets (firm size)

Market capitalization (firm size)

Slack resources

Outside director representation

Board size

\section{Measurement}

Net profit (loss) divided by the book value of equity

Total assets divided by net income

Market value of equity divided by the balance sheet (book) value of equity

Natural logarithm of total assets

Share price times the number of shares outstanding

Net profit (total sales minus total expenses)

Proportion of outside (independent) to inside (executive) board members

Total number of board members

\section{APPENDIX B: CODING SHeEt FOR CONTENT ANALYSIS}

\section{Sustainability item assessment}

\section{A.1}

A.1.1

A.1.2

A.1.3

A.1.4

A.1.5

A. 2

A.2.1

A.2.2

A.2.3

A.2.4

A.2.5

A.2.6

A.2.7

A.2.8

A.3

A.3.1

A.3.2

A.3.3

A.3.4

A.3.5
General environment (environmental quality)

Narrative on environmental policy

Narrative on environmental auditing

Narrative on improvements in product- and process-related impacts on environment

Narrative on reduction of carbon emissions

Narrative on use of environmental management system (EMS)

\section{Energy (environmental quality)}

Narrative on conservation of energy in the conduct of business operations

Narrative on using energy efficiently

Narrative on utilization of waste materials for energy production

Narrative on energy savings through recycling

Narrative on the company's efforts to reduce energy consumption

Narrative on use of alternative energy

Narrative on research aimed at improving energy efficiency of products

Narrative on the company's energy policies

\section{Human resources (social responsiveness)}

Narrative on employee code of conduct

Narrative on company's strategies on employee health and safety

Narrative on amount spent on training

Narrative on number of employees trained

Narrative on investments made in safety 


\section{APPENDIX B (CONTINUED)}

Sustainability item assessment

A.3.6 Narrative on reduction of health-related incidents

A.3.7 Narrative on strategies to ensure employee welfare

A.3.8 Narrative on human resources training initiatives

A.4 Products and customers (social responsiveness)

A.4.1 Narrative on product development initiatives

A.4.2 Narrative on product safety

A.4.3 Narrative on product quality

A.5 Community involvement (social responsiveness)

A.5.1 Narrative on donations for community activities

A.5.2 Narrative on sponsorship of public health, sporting or recreational projects

A.5.3 Narrative on aiding medical research

A.5.4 Narrative on sponsorship educational conferences, seminars or art exhibitions

A.5.5 Narrative on funding scholarship programs or activities

A.5.6 Narrative on sponsorship of national pride/government sponsored campaigns

A.5.7 Narrative on sponsorship of community self-help activities

A.5.8 Narrative on supporting the development of local industries or

community programs and activities

\section{AVAILABLE FROM ECONTENT}

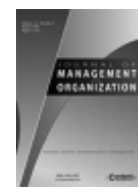

Profitable Margins: Gender and Diversity Informing Management and Organizational Studies

Special Issue of Journal of Management \& Organization - Volume 15 Issue 5

ii+126 pages - ISBN 978-1-921348-25-9 - November 2009

Editors: Alison Sheridan (University of New England), Judith Pringle (Auckland University

of Technology) and Glenda Strachan (Griffith University)

http://jmo.e-contentmanagement.com/archives/vol/15/issue/5/marketing/

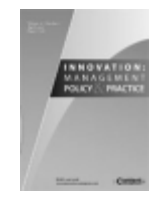

Corporate Sustainability: Governance, Innovation Strategy, Development and Methods

Special Issue of Innovation: Management, Policy \& Practice - Volume 6 Issue 2

xiv+237 pages - ISBN 978-0-9750436-2-2 - August 2004

Editors: Andrew Griffiths (The University of Queensland, Australia), Harrie Vredenburg and Jeremy Hall (TransCanada International Institute for Resource Industries and Sustainability)

http://www.innovation-enterprise.com/archives/vol/6/issue/2/marketing/ 